\title{
Morphometric analysis of Suketi river basin, Himachal Himalaya, India
}

\author{
Anil M Pophare ${ }^{1, *}$ and Umesh S Balpande ${ }^{2}$ \\ ${ }^{1}$ Department of Geology, RTM Nagpur University, Nagpur 440 001, India. \\ ${ }^{2}$ Central Ground Water Board, Central Region, Nagpur 440 001, India. \\ *Corresponding author. e-mail: apophare@gmail.com
}

Suketi river basin is located in the Mandi district of Himachal Pradesh, India. It encompasses a central inter-montane valley and surrounding mountainous terrain in the Lower Himachal Himalaya. Morphometric analysis of the Suketi river basin was carried out to study its drainage characteristics and overall groundwater resource potential. The entire Suketi river basin has been divided into five sub-basins based on the catchment areas of Suketi trunk stream and its major tributaries. Quantitative assessment of each sub-basin was carried out for its linear, areal, and relief aspects. The analysis reveals that the drainage network of the entire Suketi river basin constitutes a 7th order basin. Out of five sub-basins, Kansa khad sub-basin (KKSB), Gangli khad sub-basin (GKSB) and Ratti khad sub-basin (RKSB) are 5th order subbasins. The Dadour khad sub-basin (DKSB) is 6th order sub-basin, while Suketi trunk stream sub-basin (STSSB) is a 7th order sub-basin. The entire drainage basin area reflects late youth to early mature stage of development of the fluvial geomorphic cycle, which is dominated by rain and snow fed lower order streams. It has low stream frequency (Fs) and moderate drainage density (Dd) of $2.69 \mathrm{~km} / \mathrm{km}^{2}$. Bifurcation ratios $(\mathrm{Rb})$ of various stream orders indicate that streams up to 3rd order are surging through highly dissected mountainous terrain, which facilitates high overland flow and less recharge into the subsurface resulting in low groundwater potential in the zones of 1st, 2nd, and 3rd order streams of the Suketi river basin. The circulatory ratio (Rc) of 0.65 and elongation ratio (Re) of 0.80 show elongated nature of the Suketi river basin, while infiltration number (If) of 10.66 indicates dominance of relief features and low groundwater potential in the high altitude mountainous terrain. The asymmetry factor (Af) of Suketi river basin indicates that the palaeo-tectonic tilting, at drainage basin scale, was towards the downstream right side of the drainage basin. The slope map of Suketi river basin has been classified into three main zones, which delineate the runoff zone in the mountains, recharge zone in the transition zone between mountains and valley plane, and discharge zone in the plane areas of Balh valley.

\section{Introduction}

Drainage in any area is a surface expression of the subsurface lithology and prevailing physiographic features. Morphometric analysis of a drainage basin and its associated channel network reflect its hydrogeological behaviour and constitute base for assessment of groundwater resource potential. It expresses the interface of prevailing climate, geology, geomorphology, and structure of the basin. The relationship between various drainage parameters and these factors are well established (Horton 1932, 1945; Strahler 1957; Melton 1958a; Leopold et al. 1964; Cannon 1976; Pakhmode et al.

Keywords. Morphometric analysis; drainage characteristics; groundwater resources; Suketi river basin; Himachal Himalaya; India. 
2003; Gangalakunta et al. 2004). Many studies have demonstrated the utility of geomorphic indices for evaluating adjustment of a drainage network to recent uplift (Delcaillau 2001; Ponza et al. 2010), structural control (Beneduce et al. 2004; Capolongo et al. 2005; Gioia and Schiattarella 2010; Gioia et al. 2011b), and tectonic tilting (Salvany 2004; Gioia et al. 2011a). These studies are important for planning the future groundwater development and management.

Several important rivers originate from the Himalaya that belong to the Indus river system and Ganga river system (Pirta 2006). Suketi river is a major tributary of Beas river that forms part of the Indus river system. Suketi river basin is situated in the Lower Himachal Himalayas, in the Mandi district of Himachal Pradesh, India, between two major towns, i.e., Mandi towards the north and Sundernagar towards the south. The basin covers a geographical area of $422 \mathrm{~km}^{2}$, spread in the topographical sheet nos. $53 \mathrm{~A} / 14,53 \mathrm{~A} / 15,53$ $\mathrm{E} / 2$, and $53 \mathrm{E} / 3$ and located between the latitude $31^{\circ} 27^{\prime} 08^{\prime \prime}: 31^{\circ} 45^{\prime} 00^{\prime \prime}$ and longitude $76^{\circ} 48^{\prime} 20^{\prime \prime}$ : $77^{\circ} 03^{\prime} 09^{\prime \prime}$ (figure 1). The Suketi river basin has a peculiar physiographic character. It has a centrally located inter-montane valley that covers an area of $79 \mathrm{~km}^{2}$, popularly known as Balh valley and surrounding mountainous terrain covering an area of $343 \mathrm{~km}^{2}$. The average surface elevation of Balh valley is about $790 \mathrm{~m}$ above mean sea level (msl), whereas the altitude of mountains varies from 800 to $\sim 2900 \mathrm{~m}$ above msl. The Balh valley is underlain by thick Quaternary valley fill material, whereas the surrounding mountainous terrain is dominated by hard rock terrain (Srikantia and Bhargava 1998; Das and Haake 2003; Das and Kaur 2007; Bhargava et al. 2011).

In Balh valley area of the Suketi river basin, most of the drinking and irrigation water supply is based on dug wells and tube wells, whereas in the mountainous terrain it is based on spring and bore well sources. In recent years, most of the perennial spring sources and small nallas in the mountainous terrain are either dried up or their discharge has been reduced significantly. As a result, water scarcity is prevalent in most of the villages and small hamlets located near the spring sources, during summer from mid March up to the onset of monsoon. This can be attributed to several factors like impact of climate change on precipitation patterns such as rise in rainfall intensity, reduction in its temporal spread, and marked decline in winter rains, etc. Along with other anthropogenic causes and high relief in the mountains, where groundwater recharge is less than the runoff generated, the problem of fading springs is being increasingly felt across the Himalaya region (Tambe et al. 2012).
Though, the entire Suketi river basin falls under assured rainfall zone, most of the rainfall is lost as surface runoff, without infiltrating into the subsurface, due to rapid overland flow on the steep gradient of the mountains and impermeable lithology. Moreover, springs of the study area are mostly fracture springs and recharge areas of such springs are located in the upstream that fall in low groundwater recharge zones. Thus, there is prevalent water scarcity in the mountainous terrain, leading to overall change in the groundwater regime of the entire Suketi river basin. This scenario necessitates implementation of suitable water conservation measures for increasing the groundwater resource potential of Suketi river basin, in general and mountainous terrain, in particular. With this objective, the morphometric analysis of Suketi river basin has been carried out along with the drainage characteristics and their relevance to overall groundwater resource potential of the basin.

\section{Geological framework and hydrogeology}

Himachal Himalaya can be broadly divided into two major geotectonic zones, viz., the Lesser Himalayan Tectogen in the south and the Tethys Himalayan Tectogen towards the north. These tectonic zones are juxtaposed along a major tectonic break collectively designated as Main Central Thrust (MCT). These two tectonic zones are characterised by exposed lithounits of different epochs, stratigraphy, lithostructural features, and faunal assemblages along with diverse sedimentological, magmatic, and tectonic elements. The Suketi river basin was formed along two major thrusts, viz., the Mandi thrust and the Main Central Thrust. The intermontane Balh valley is located in between these two longitudinal thrusts (figure 1) (Srikantia 1987, 1988; Srikantia and Bhargava 1998; Vaidyanandan and Ramakrishnan 2008).

Rock formations of the Proterozoic and Cenozoic periods are well exposed in the Suketi river basin. The Proterozoic metasediments belong to Salkhala, Sundernagar, and Shali groups. The Dhauladhar granite intrusion separates the Lower Salkhala Group from Upper Sundernagar Group. The Cenozoic sediments belong to Subathu and Siwalik groups, which have the capping of Quaternary alluvium (Srikantia and Bhargava 1998). The eastern sector of Suketi river basin is occupied by granite, gneisses, quartzites, and phyllites, whereas the western part is occupied by sandstone, phyllite, schists, dolomites, limestones, quartzites, etc. The Quaternary alluvium is unconsolidated sediments, restricted in the Balh valley and comprises of boulders, cobbles, pebbles, gravels, sand, silt, and clay (figure 1). 


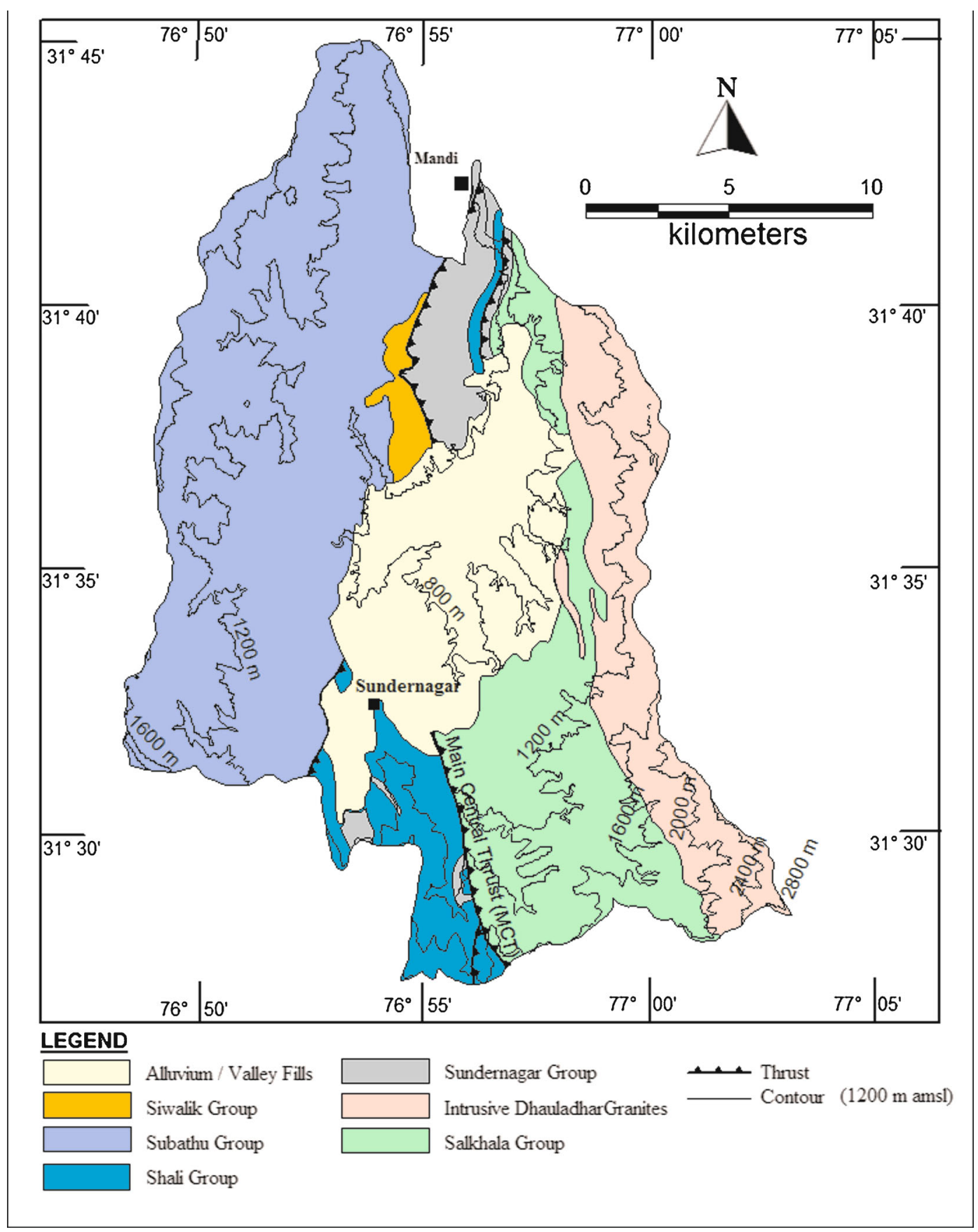

Figure 1. Geological map of the Suketi river basin, Mandi District, Himachal Pradesh (modified after Srikantia 1987; Srikantia and Bhargava 1998).

The Suketi river basin has abundant surface water resources and huge groundwater potential, confined to the Balh valley area. This basin is drained by the river Suketi and its major tributaries like Chail khad, Kansa khad, Gangli khad, Dadour khad, and Ratti khad (Pirta 2006). Suketi, a perennial river, is both rain fed as well as snow fed. It originates from an altitude of $2890 \mathrm{~m}$ above msl in the southeastern part of the basin, and discharges water at an altitude of $760 \mathrm{~m}$ above msl in its northernmost part, where it joins the river Beas (figures 2 and 3). Huge sediment accumulation in the Balh valley and southerly flow of the tributary Ratti khad indicates drainage reversal in the Suketi river basin due to palaeo-tectonic activities (Bhargava et al. 2011).

Springs and bore wells are important groundwater sources in the mountainous terrain of the Suketi river basin. The springs are either depression or fracture springs and represent shallow 


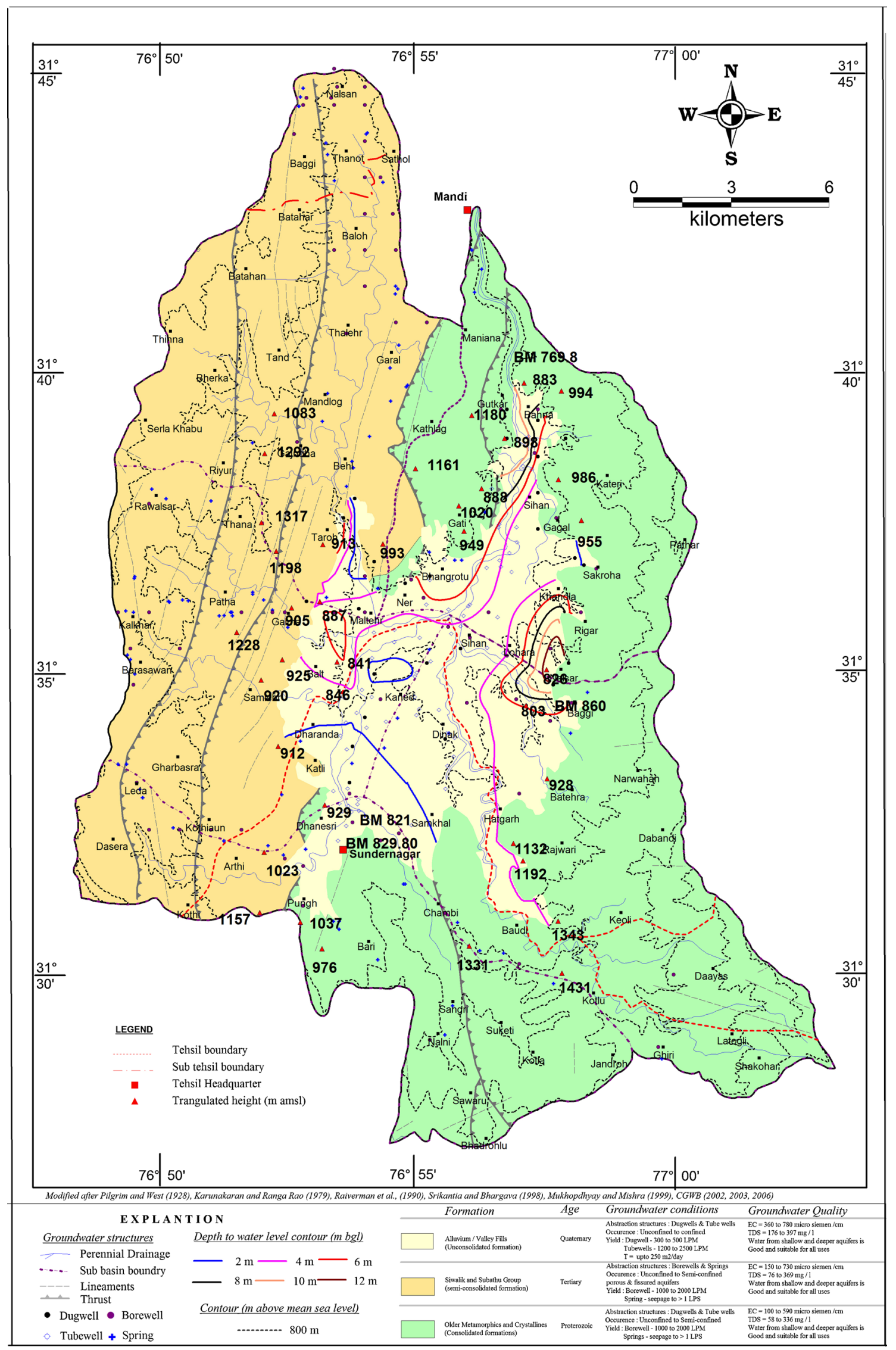

Figure 2. Hydrogeological map of the Suketi river basin. 


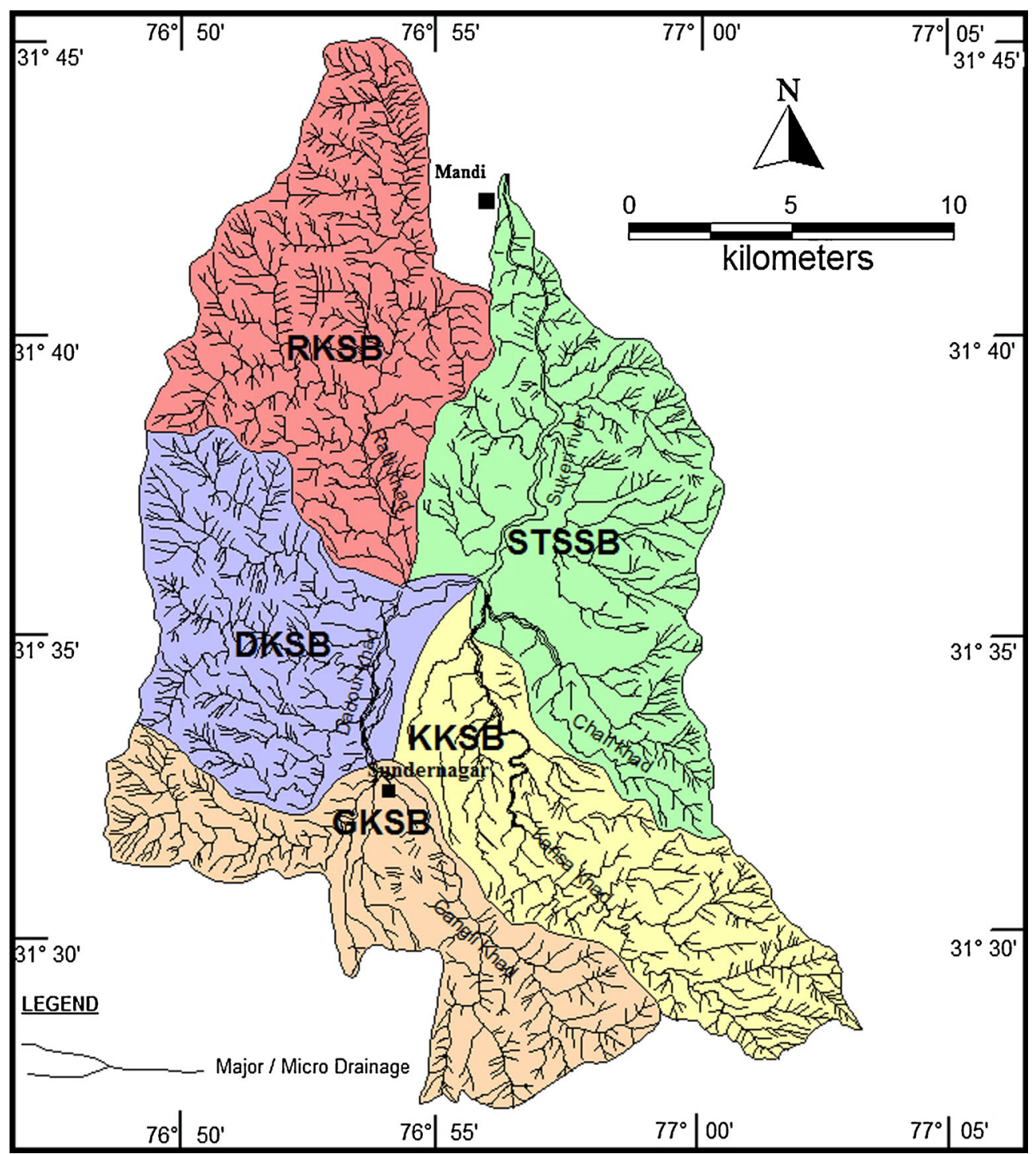

Figure 3. Drainage map of the Suketi river basin with sub-basin boundaries.

aquifers in the mountains (figure 2). The spring sources have low groundwater potential as they discharge water mostly in the form of seepage and become dry during summer. However, discharge of spring sources located in the Shali limestone at Nalni and Nagchala areas and in the sandstone at Rewalsar area was observed to be more than 10 liters/second (lps). During 2009-2010, hydrogeological studies were carried out in the Suketi river basin in order to evaluate the discharge characteristics of the spring sources. These studies revealed that during pre-monsoon seasons most of the fracture springs were found to be dry, whereas during post-monsoon seasons these springs got revived due to infiltration of rainwater through fractures and joints. However, infiltration of rainwater lasted for a short duration thereby restricting the quantity of recharge through the spring sources, in the absence of suitable water conservation measures.
Bore wells in the high altitude mountains of the Suketi river basin derive groundwater from deeper zones of the consolidated or semi-consolidated formations (figure 2). The depth of bore wells generally ranges from more than 50-70 m below ground level ( $\mathrm{m} \mathrm{bgl}$ ). Most of these bore wells are fitted with hand pumps; however, few bore wells with adequate discharge are fitted with power pumps. Bore well water is utilised for drinking and domestic purposes, whereas surface flow diverted through kuhls (channels) is used for small scale irrigation by the populace residing in the mountains.

In the Balh valley area of Suketi river basin, dug wells and tube wells are prominent groundwater abstraction structures that derive groundwater from the phreatic and semi-confined to confined aquifers, respectively. Dug wells essentially represent shallow aquifers with maximum depth of $15 \mathrm{~m}$ bgl, whereas tube wells are deep and high capacity wells with depth range from 50 to $100 \mathrm{~m}$ bgl. Tube 
wells derive groundwater from multilayered deeper aquifers consisting of granular materials like sand, gravel, pebbles, and cobbles (figure 2).

The Suketi river basin receives precipitation in the form of rainfall during monsoon period from June to September. The average annual rainfall in the Mandi district is about $1136 \mathrm{~mm}$ with average rainy days of 55-75 (CGWB 2001, 2006, 2007). The mountain peaks of the study area experience snowfall during winter, which often comes down to $1300 \mathrm{~m}$ for a short period (Pirta 2006).

\section{Materials and methods}

Morphometric analysis of Suketi river basin was carried out by using the Survey of India, topographical sheets nos. $53 \mathrm{~A} / 14,53 \mathrm{~A} / 15,53 \mathrm{E} / 2$ and $53 \mathrm{E} / 3$ on 1:50,000 scale. A base map was prepared by joining all four topographical sheets of the study area. The map was georeferenced with the help of GIS software (MapInfo 6.5). The drainage network of Suketi river basin and contours of 100 $m$ interval was accurately digitized for the analysis of linear, areal, and relief aspects of the drainage basin. The relief and slope studies were carried out using field data, topographical sheets, and base map of the study area along with the Shuttle Radar Topography Mission (SRTM) digital data available on the website of United States Geological Survey (USGS) (http://dds.cr.usgs.gov/srtm/Version2_1/ SRTM3/Eurasia/) through the software Global Mapper 13.0 version.

Five major sub-basins within the Suketi river basin were identified and delineated on the topographic base map considering the catchment areas of major tributaries/khads of the Suketi river, viz., Kansa khad (Kansa khad sub-basin, KKSB), Gangli khad and drainage from the extreme southern streams (Gangli khad sub-basin, GKSB), Dadour khad (Dadour khad sub-basin, DKSB), Ratti khad (Ratti khad sub-basin, RKSB) and Suketi trunk stream (Suketi trunk stream subbasin, STSSB) (figure 3). The drainage network of Suketi river basin is analysed as per the laws of Horton (1945) and stream ordering is done after Strahler (1964) on 1:50,000 scale topographic base map. All the parameters for drainage morphometric analysis were calculated using standard formulae.

\section{Drainage pattern and morphometric analysis}

In Suketi river basin, the overall drainage pattern is dendritic to sub-dendritic (figure 3). The dendritic drainage pattern is independent of structural and lithological controls and is one of the dominant drainage patterns in the Himalayas (Singh 1998b). The drainage in RKSB, drained by Ratti khad, is structurally controlled at many places and appears as the rectangular drainage pattern (figure 3). This can be attributed to the $\mathrm{NE}-$ SW trending high altitude mountain ranges in the western part of Suketi river basin, which consist of folded rocks of Subathu Group and are largely affected by joints, fractures, and faults. The network of streams in RKSB follows these lines of weakness and joins their master streams at right angles, showing rectangular drainage pattern at places. Glimpses of radial drainage pattern are observed in the central part of GKSB that constitute the southern part of Suketi river basin. In this sub-basin, radial drainage pattern is formed on a dome-shaped mountain composed of quartzite (figures 1 and 3 ).

Systematic description of the geometry of a drainage basin and its stream-channel system requires measurement of the linear aspects of drainage network, areal aspects of the drainage basin, and relief (gradient) aspects of the channel network along with contributing ground slopes (Chow 1964). These morphometric parameters impart information on various terrain factors like nature of bedrock, infiltration capacity, runoff, and denudation characteristics of the area (Rao et al. 2010).

\subsection{Linear aspects of the basin}

Linear aspects of a drainage network reveal the behaviour of a river and its tributaries from head to mouth and reflect lithological and structural controls of the drainage basin. The important linear aspects of a drainage basin includes stream order, stream number, bifurcation ratio, mean bifurcation ratio, stream length, mean stream length, and stream length ratio.

The streams of Suketi river basin have been graded according to the Strahler's stream ordering system (Strahler 1964). The entire Suketi river basin contains 1672 streams of all orders in its geographical area, and it is designated as 7 th order basin. Out of five sub-basins, KKSB, GKSB, and RKSB are 5th order sub-basins, DKSB is a 6 th order sub-basin, while STSSB is a 7 th order sub-basin as it contains streams up to 7 th order (table 1; figure 3). In Suketi river basin, the streams of 1st order are highest out of the total number of streams, whereas the streams of next order are subsequently reduced (table 1), which is as per Horton's law (Horton 1932, 1945). Bivariate analysis of total stream numbers and the stream order on a log-normal plot show linear relationship with minor deviation from the straight line, 
Table 1. Linear aspects of the Suketi river basin.

\begin{tabular}{|c|c|c|c|c|c|c|}
\hline Parameter & KKSB & GKSB & DKSB & RKSB & STSSB & $\begin{array}{c}\text { Suketi river } \\
\text { basin }\end{array}$ \\
\hline \multicolumn{7}{|l|}{ Stream order and stream numbers } \\
\hline $1^{\text {st }}$ order $(\mathrm{Nu} 1)$ & 227 & 220 & 237 & 362 & 257 & 1303 \\
\hline $2^{\text {nd }}$ order $(\mathrm{Nu} 2)$ & 36 & 43 & 53 & 78 & 72 & 282 \\
\hline $3^{\text {rd }}$ order $(\mathrm{Nu} 3)$ & 10 & 9 & 9 & 16 & 17 & 61 \\
\hline $4^{\text {th }}$ order $(\mathrm{Nu} 4)$ & 2 & 3 & 4 & 3 & 4 & 16 \\
\hline $5^{\text {th }}$ order $(\mathrm{Nu} 5)$ & 1 & 1 & 2 & 1 & 2 & 7 \\
\hline $6^{\text {th }}$ order $(\mathrm{Nu} 6)$ & - & - & 1 & - & 1 & 2 \\
\hline $7^{\text {th }}$ order $(\mathrm{Nu} 7)$ & - & - & - & - & 1 & 1 \\
\hline Total & 276 & 276 & 306 & 460 & 354 & 1672 \\
\hline \multicolumn{7}{|l|}{ Bifurcation ratio (Rb) } \\
\hline $1^{\mathrm{st}} / 2^{\mathrm{nd}}$ & 6.31 & 5.12 & 4.47 & 4.64 & 3.57 & 4.62 \\
\hline $2^{\text {nd }} / 3^{\text {rd }}$ & 3.6 & 4.78 & 5.89 & 4.88 & 4.24 & 4.62 \\
\hline $3^{\mathrm{rd}} / 4^{\text {th }}$ & 5 & 3 & 2.25 & 5.33 & 4.25 & 3.81 \\
\hline $4^{\text {th }} / 5^{\text {th }}$ & 2 & 3 & 2 & 3 & 2 & 2.29 \\
\hline $5^{\text {th }} / 6^{\text {th }}$ & - & - & 2 & - & 2 & 3.5 \\
\hline $6^{\text {th }} / 7^{\text {th }}$ & - & - & - & - & 1 & 2 \\
\hline Mean bifurcation ratio (Rbm) & 4.23 & 3.97 & 3.32 & 4.46 & 3.21 & 3.47 \\
\hline \multicolumn{7}{|l|}{ Stream length } \\
\hline $1^{\text {st }}$ order $(\mathrm{Lu} 1)$ & 109.67 & 116.33 & 121.28 & 173.05 & 128.66 & 648.99 \\
\hline $2^{\text {nd }}$ order $(\mathrm{Lu} 2)$ & 47.18 & 38.29 & 36.83 & 56.50 & 45.92 & 224.72 \\
\hline $3^{\text {rd }}$ order $(\mathrm{Lu} 3)$ & 16.01 & 15.77 & 22.24 & 33.58 & 36.27 & 123.87 \\
\hline $4^{\text {th }}$ order $(\mathrm{Lu} 4)$ & 12.67 & 17.14 & 13.56 & 16.33 & 11.81 & 71.51 \\
\hline $5^{\text {th }}$ order $(\mathrm{Lu} 5)$ & 16.91 & 6.85 & 5.69 & 9.95 & 7.29 & 46.69 \\
\hline $6^{\text {th }}$ order (Lu6) & - & - & 3.39 & - & 0.87 & 4.26 \\
\hline $7^{\text {th }}$ order $(\operatorname{Lu} 7)$ & - & - & - & - & 15.76 & 15.76 \\
\hline Total & 202.44 & 194.38 & 202.99 & 289.41 & 246.58 & 1135.80 \\
\hline \multicolumn{7}{|l|}{ Mean stream length (Lsm) } \\
\hline $1^{\text {st }}$ order $(\mathrm{Lsm} 1)$ & 0.49 & 0.53 & 0.51 & 0.48 & 0.50 & 0.50 \\
\hline $2^{\text {nd }}$ order $(\operatorname{Lsm} 2)$ & 1.31 & 0.89 & 0.69 & 0.72 & 0.64 & 0.80 \\
\hline $3^{\text {rd }}$ order $(\operatorname{Lsm} 3)$ & 1.60 & 1.75 & 2.47 & 2.10 & 2.13 & 2.03 \\
\hline $4^{\text {th }}$ order $(\operatorname{Lsm} 4)$ & 6.33 & 5.71 & 3.39 & 5.44 & 2.95 & 4.47 \\
\hline $5^{\text {th }}$ order $(\operatorname{Lsm} 5)$ & 16.91 & 6.85 & 2.85 & 9.95 & 3.65 & 6.67 \\
\hline $6^{\text {th }}$ order $(\operatorname{Lsm} 6)$ & - & - & 3.39 & - & 0.87 & 2.13 \\
\hline $7^{\text {th }}$ order $(\operatorname{Lsm} 7)$ & - & - & - & - & 15.76 & 15.76 \\
\hline \multicolumn{7}{|l|}{ Stream length ratio } \\
\hline $2^{\mathrm{nd}} / 1^{\mathrm{st}}$ & 0.43 & 0.33 & 0.30 & 0.33 & 0.36 & 0.35 \\
\hline $3^{\mathrm{rd}} / 2^{\text {nd }}$ & 0.34 & 0.41 & 0.60 & 0.59 & 0.79 & 0.55 \\
\hline $4^{\text {th }} / 3^{\text {rd }}$ & 0.79 & 1.09 & 0.61 & 0.48 & 0.33 & 0.58 \\
\hline $5^{\text {th }} / 4^{\text {th }}$ & 1.33 & 0.40 & 0.42 & 0.61 & 0.62 & 0.65 \\
\hline $6^{\text {th }} / 5^{\text {th }}$ & - & - & 0.60 & - & 0.12 & 0.09 \\
\hline $7^{\text {th }} / 6^{\text {th }}$ & - & - & - & - & 18.11 & 3.70 \\
\hline
\end{tabular}

where the number of stream segments decreases as stream order increases (figure 4) (Horton 1945; Chow 1964).

Bifurcation ratio $(\mathrm{Rb})$ is the ratio between the total number of stream segments of one order to that of the next higher order in a drainage basin (Schumm 1956, 1963). Rb varies from a minimum of 2 in flat or rolling drainage basins to 3 or 4 in mountainous or highly dissected drainage basins (Horton 1945). In Suketi river basin, bifurcation ratios of various stream orders range between 3 and 5 (table 1). This indicates that streams up to 3rd order are surging through highly dissected and steep gradient mountainous terrain, which facilitates high overland flow and less water recharge into the subsurface. Hence, groundwater potential is low in the zones of 1st, 2nd, and 3rd order streams of Suketi river basin. The mean bifurcation ratios (Rbm) of all the five sub-basins of Suketi river basin range from 3.21 to 4.46 (table 1), which 
indicates that STSSB and RKSB are relatively more elongated followed by GKSB, while DKSB is least elongated (figure 3) (Strahler 1957, 1964; Morisawa 1985; Ansari et al. 2012).

In Suketi river basin, the total length of stream segments is highest in 1st order streams and decreases as the stream order increases indicating that the catchment is in conformity with the Horton's law of stream numbers and stream lengths (table 1) (Horton 1932, 1945; Strahler 1964). The log-normal plot of stream length $v s$. stream order reveals linear declining trend (figure 5), which indicates that the mountainous terrain of Suketi river basin is characterised by variation in topography, gradient, and lithology. The GKSB of Suketi river basin has maximum mean stream length (Lsm) of $0.53 \mathrm{~km}$ for 1st order streams, while STSSB has maximum Lsm of $15.76 \mathrm{~km}$ for 7 th order stream (table 1). This implies that the maximum length of drainage basin, parallel to the main drainage, starts from GKSB and ends in STSSB (figure 3). The stream length ratio (RL) between the streams of different orders in each sub-basin of the Suketi river basin is variable (table 1) (Horton 1945). This variation in RL from one order to another, in all the sub-basins indicates that the Suketi river basin is transient through late youth to early mature stage of development of the fluvial geomorphic cycle (Singh and Singh 1997; Singh et al. 2003).

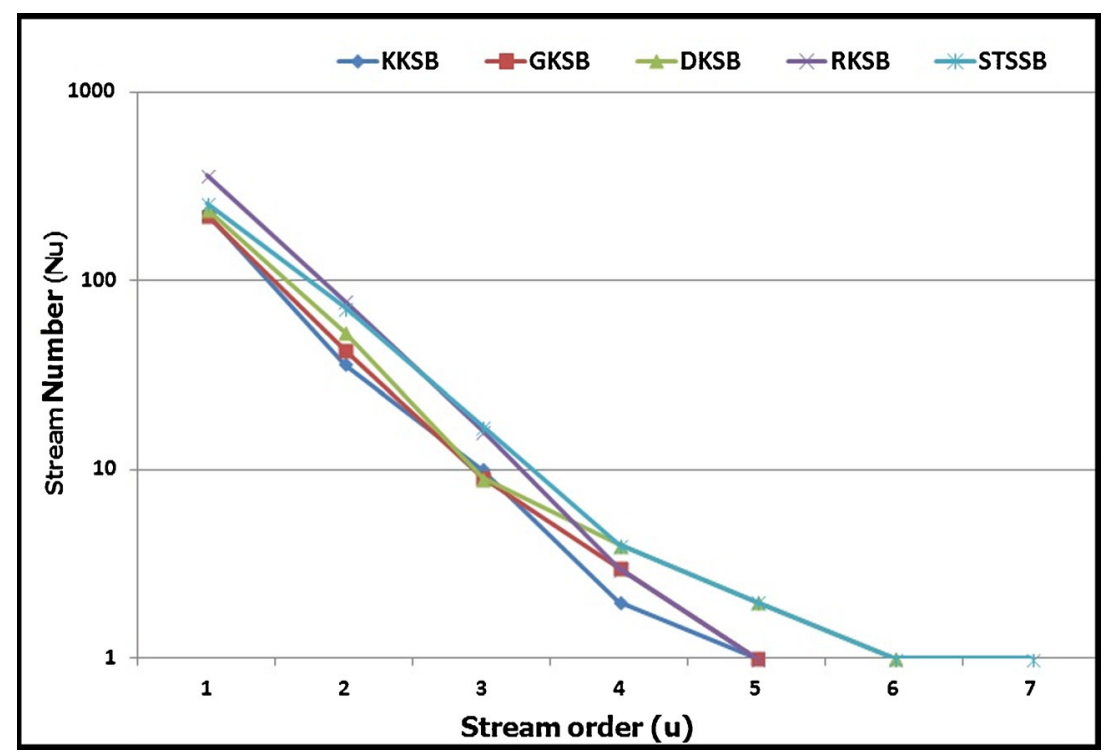

Figure 4. Stream order vs. stream number plot of sub-basins STSSB, KKSB, GKSB, DKSB, RKSB and the Suketi river basin.

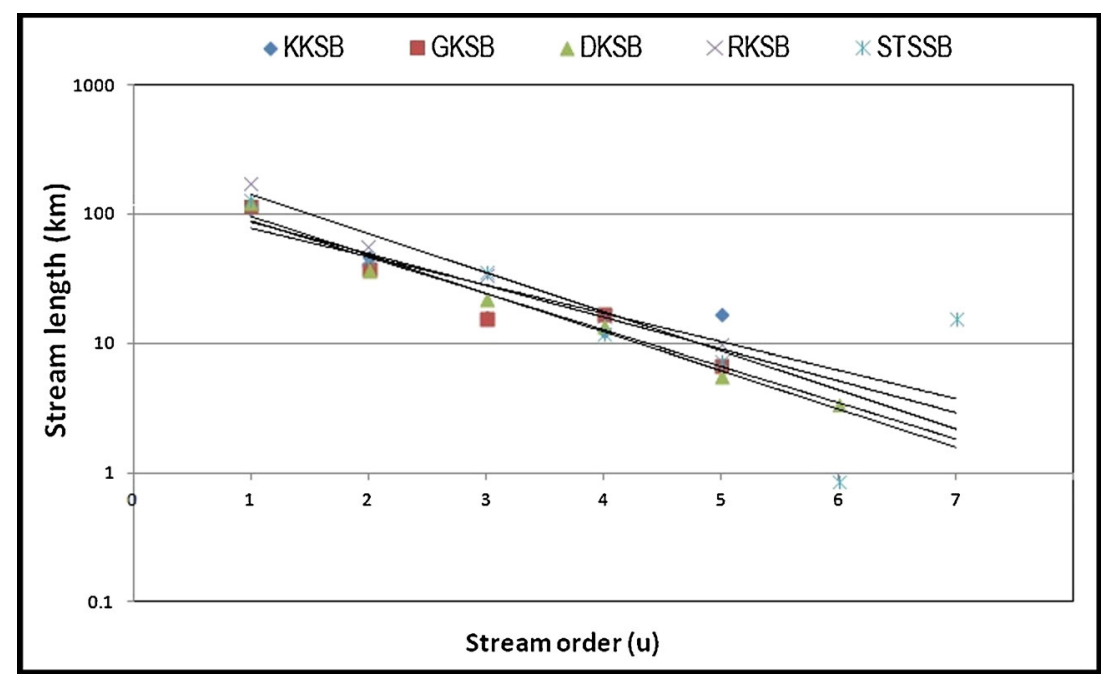

Figure 5. Stream order vs. stream length plot of sub-basins STSSB, KKSB, GKSB, DKSB, RKSB and the Suketi river basin. 


\subsection{Areal aspects of the basin}

The areal aspects of a drainage basin reveal regional features like lithology, geological structure, climatic conditions, and denudation history of the basin. These aspects control the spatial arrangement, geometrical shape and form of drainage systems, river discharge, and runoff characteristics (Singh 1998b). Aerial aspects of a drainage basin includes basin area, basin perimeter, basin length, circulatory ratio, elongation ratio, form factor, drainage density, drainage texture, stream frequency, infiltration number, length of overland flow, constant of channel maintenance, lemniscates ratio, sinuosity index and ellipticity index.

The total geographical area, perimeter, and length of the Suketi river basin is about $422 \mathrm{~km}^{2}$, $112.30 \mathrm{~km}$ and $28.91 \mathrm{~km}$, respectively. The shape of a drainage basin is dependent on circulatory ratio, elongation ratio, and form factor, which has a profound influence on the runoff and sediment transport processes. The values of these ratios for Suketi river basin indicates overall elongated nature of the entire drainage basin and subbasins along with dominance of strong relief and steep ground slope (table 2). The Suketi river basin has overall moderate drainage density of 2.69 $\mathrm{km} / \mathrm{km}^{2}$, whereas the five sub-basins have coarse to moderate drainage densities, which indicates presence of relatively impermeable subsoil and low groundwater potential. Further, the Suketi river basin and the sub-basins reveal moderate to very fine drainage texture (table 2).

The entire drainage area of Suketi river basin and the five sub-basins has low stream frequencies. The high infiltration numbers of the five subbasins and the Suketi river basin indicate dominance of relief features, hard and impermeable lithology resulting into less water infiltration, and high runoff in the entire drainage basin (Smith 1950) (table 2). High values of infiltration numbers also point towards low groundwater potential in the steeply sloping mountainous terrain of the Suketi river basin. Moreover, Suketi river basin and sub-basins encompass almost straight channels, where runoff quickly enters into the streams without infiltrating into the subsurface (table 2) (Schumm 1963; Singh 1998a, b). These aspects suggest immediate necessity of water conservation measures in the upstream catchment areas of the Suketi river basin, to enhance infiltration of surface runoff into the sub-surface for revival and sustenance of the spring sources.

\subsection{Relief aspects of the basin}

Relief aspects of a drainage basin imitate the topographical gradient characteristics of the basin and

Table 2. Aerial and relief aspects of the Suketi river basin.

\begin{tabular}{|c|c|c|c|c|c|c|}
\hline Parameter & KKSB & GKSB & DKSB & RKSB & STSSB & $\begin{array}{c}\text { Suketi river } \\
\text { basin }\end{array}$ \\
\hline \multicolumn{7}{|l|}{ Aerial aspects of the basin/sub-basins } \\
\hline Basin area $\left(\mathrm{km}^{2}\right)$ & 76.28 & 71.75 & 73.93 & 94.97 & 105.07 & 422.00 \\
\hline Basin perimeter $(\mathrm{P})(\mathrm{km})$ & 46.43 & 54.38 & 38.54 & 46.96 & 54.61 & 112.30 \\
\hline Basin length (Lb) (km) & 18.17 & 17.16 & 11.28 & 9.41 & 21.51 & 28.91 \\
\hline Circulatory ratio $(\mathrm{Rc})$ & 0.67 & 0.55 & 0.79 & 0.74 & 0.67 & 0.65 \\
\hline Elongation ratio $(\mathrm{Re})$ & 0.54 & 0.56 & 0.86 & 1.17 & 0.54 & 0.80 \\
\hline Form factor (Rf) & 0.23 & 0.24 & 0.58 & 1.07 & 0.23 & 0.50 \\
\hline Drainage density (Dd) & 2.65 & 2.71 & 2.75 & 3.05 & 2.35 & 2.69 \\
\hline Drainage texture (Rt) & 5.94 & 5.08 & 7.94 & 9.80 & 6.48 & 14.89 \\
\hline Stream frequency (Fs) & 3.62 & 3.85 & 4.14 & 4.84 & 3.37 & 3.96 \\
\hline Infiltration number (If) & 9.60 & 10.42 & 11.36 & 14.76 & 7.90 & 10.66 \\
\hline Length of overland flow ( $\mathrm{Lg}$ ) & 0.19 & 0.18 & 0.18 & 0.16 & 0.21 & 0.19 \\
\hline Constance of channel maintenance (C) & - & - & - & - & - & 0.37 \\
\hline Lemniscate ratio (Lr) & 1.08 & 1.03 & 0.43 & 0.23 & 1.10 & 0.50 \\
\hline Sinuosity index (SI) & 1.63 & 1.65 & 1.20 & 1.58 & 1.33 & 1.61 \\
\hline Ellipticity index (E) & 3.40 & 3.22 & 1.35 & 0.73 & 3.46 & 1.55 \\
\hline \multicolumn{7}{|l|}{ Relief aspects of the basin/sub-basins } \\
\hline Highest elevation $(\mathrm{Z})(\mathrm{m})$ & 2890 & 1970 & 1930 & 2010 & 2000 & 2890 \\
\hline Lowest elevation $(\mathrm{z})(\mathrm{m})$ & 775 & 820 & 775 & 829 & 760 & 760 \\
\hline Basin relief $(\mathrm{H})(\mathrm{m})$ & 2115 & 1150 & 1155 & 1181 & 1240 & 2130 \\
\hline Relief ratio ( $\mathrm{Rh})$ & 0.12 & 0.07 & 0.10 & 0.13 & 0.06 & 0.07 \\
\hline Relative relief (Rhp) & 4.55 & 2.11 & 2.99 & 2.51 & 2.27 & 1.90 \\
\hline Ruggedness number (HD) & 5.61 & 3.11 & 3.17 & 3.60 & 2.91 & 5.73 \\
\hline Meandering ratio (Mr) & - & - & - & - & - & 0.62 \\
\hline
\end{tabular}


provide a bird's eye view of the entire area. The relief aspects of a drainage basin include elevation of highest and lowest points in the basin, basin relief, relief ratio, relative relief, ruggedness number, meandering ratio, and slope.

In Suketi river basin, the highest and lowest elevations are observed in KKSB and STSSB. The KKSB has maximum basin relief of $2115 \mathrm{~m}$ and GKSB has lowest basin relief of $1150 \mathrm{~m}$ (table 2). Moreover, the low relief ratios and relative relief of Suketi river basin and sub-basins indicate the presence of less resistant rocks in the drainage basin (Melton 1958b; Singh et al. 2003). Ruggedness number (HD) and meandering ratio (Mr) (table 2) of the Suketi river basin signify rugged nature of the drainage basin area except STSSB, which occupies lowest relief in the entire basin and indicates mature terrain (Strahler 1964; Patton 1988; Roohani and Gupta 1988; Saud 2009).

The slope elements in any terrain are controlled by climate and morphogenic processes operating in the underlying rocks (Strahler 1950, 1952; Yeh e al. 2009). Slope characteristics of Suketi river basin is derived from the topographic maps of the study area and SRTM data available on the USGS website. Three main slope zones are identified in the Suketi river basin, which can be correlated with three major physiographic units (figure 6). The first zone is the outermost zone and represents high altitude mountainous terrain surrounding the Balh valley of Suketi river basin and has a slope of more than $10^{\circ}$. This zone of steep slopes represents the runoff zone of Suketi river basin. The second zone is the intermediate zone of Suketi river basin and has

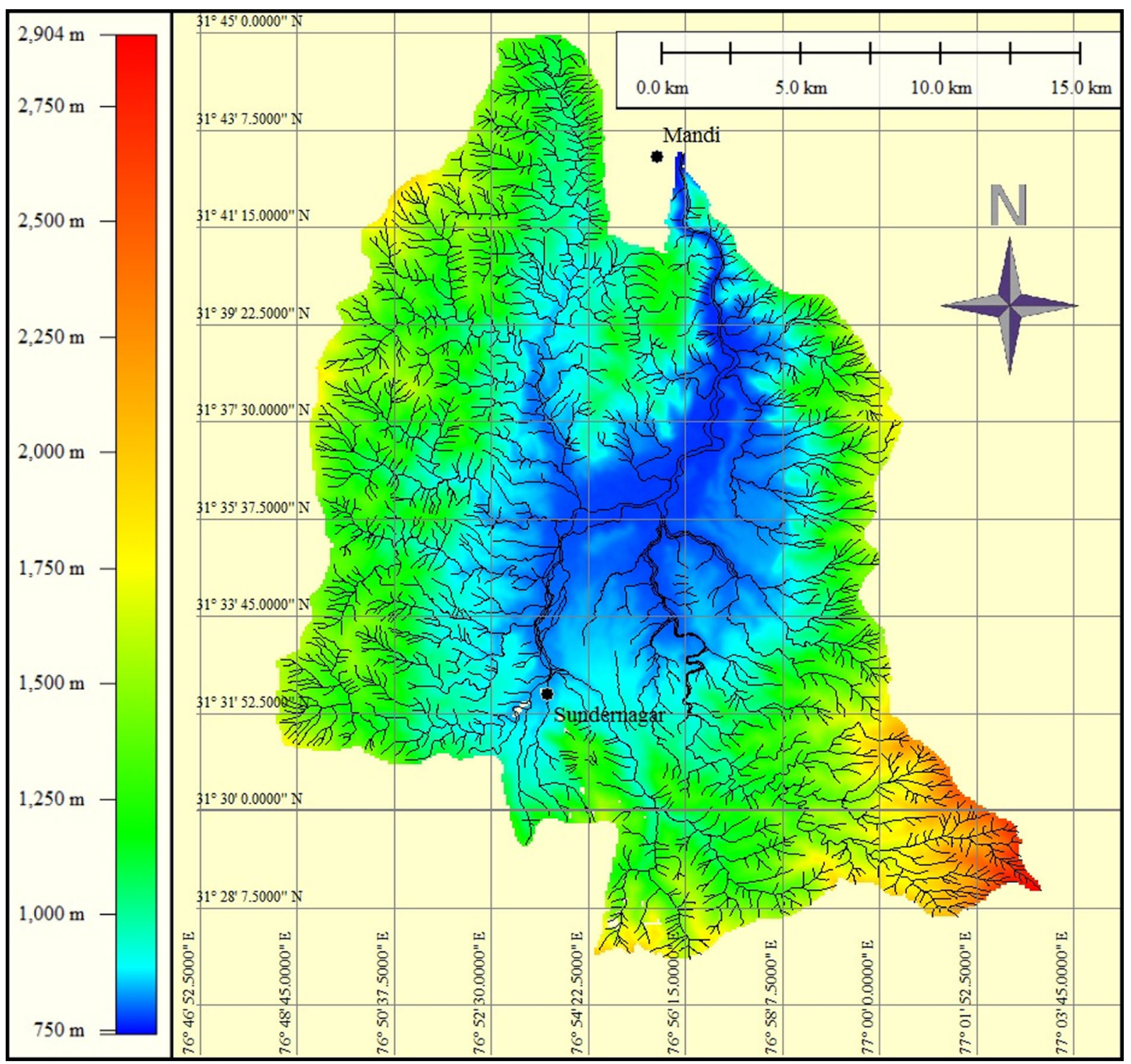

Figure 6. Digital Elevation Model (DEM) of the Suketi river basin. 
moderate slope between $5^{\circ}$ and $10^{\circ}$. It is the transition zone between the high altitude mountains and valley plane and represents the main recharge zone of the drainage basin. The third zone is the innermost zone of the Suketi river basin having gentle slope of less than $5^{\circ}$. This zone coincides with the plane area of Balh valley and represents the discharge zone of the Suketi river basin (figure 6).

\subsection{Longitudinal profile}

Longitudinal profiles of channels are useful in deriving information related to recent regional or local active tectonic activities (Hack 1957, 1973; Burnett and Schumm 1983; Seeber and Gornitz 1983; Ouchi 1985; Keller 1986; Merritts and Vincent 1989; Rhea 1989, 1993). Longitudinal profile of alluvial channels and many bedrock-alluvial channels are typically concave up, a shape equated with equilibrium profile, where driving force is equivalent to the resistant force. However, when a river passes through the zones of active tectonics (subsidence or uplift) its longitudinal profile show effects of deformation. Therefore, river longitudinal profile and its corresponding concavity and steepness are used to characterise the tectonics and base level fall (Mackin 1948; Gomez et al. 1996; Demoulin 1998; Holbrook and Schumm 1999; Schumm et al. 2000; Marple and Talwani 2000; Lavé and Avouac 2000, 2001; Kirby and Whipple 2001). The longitudinal profile of Suketi river deviates significantly from the simple concave-up shape and shows steep fall in its initial travel from the high altitude mountainous terrain consisting of hard rocks. Subsequently, it travels down through the contact between hard and soft rocks and finally through the alluvial tract of Balh valley. The longitudinal profile of Suketi river points towards the preponderance of palaeo-tectonic activities in shaping the drainage basin geometry (figure 6).

\subsection{Asymmetry factor (Af)}

Asymmetry factor represents drainage basin asymmetry and helps in determining the general tilt of the basin landscape irrespective of whether the tilt was due to local or regional tectonic deformation, at drainage basin scale (Hare and Gardner 1984; Gardner et al. 1987; Keller and Pinter 2002). This parameter is calculated using the equation of Gardner et al. (1987).

$$
\operatorname{Asymmetry} \text { factor }(\mathrm{Af})=100\left(\frac{\mathrm{Ar}}{\mathrm{At}}\right)
$$

where $\mathrm{Ar}=$ area of the right (facing downstream) of the trunk stream and At $=$ total area of the drainage basin.

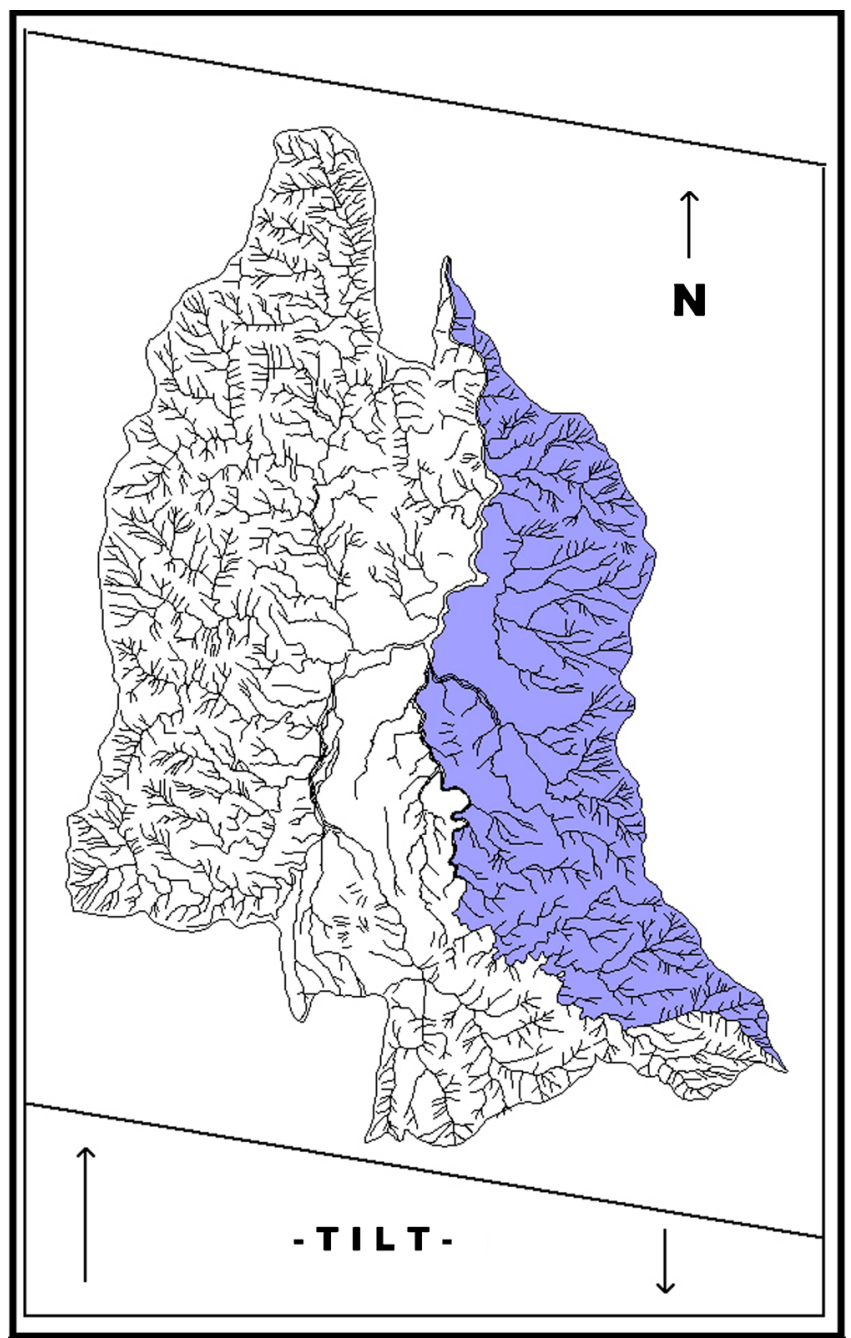

Figure 7. Block diagram showing tilting of Suketi river at the drainage basin scale.

The Af above or below 50 may result from basin tilting, resulting either from active tectonics or lithologic/structurally controlled differential erosion. Af value of $>50 \%$ indicates that the basin area has tilted towards the downstream left side. Whereas, Af value of $<50 \%$ indicates that the basin has tilted towards the downstream right side (Hare and Gardner 1984). For Suketi river basin, the Af value of $18.39 \%$ and negative differential value of Af-50 suggest that the basin has tilted towards the downstream right side (figure 7) (cf. Keller and Pinter 2002; Pankaj and Kumar 2009; Ahmed and Bhat 2012).

\section{Discussion}

The morphometric analysis carried out in the Suketi river basin reveals that the drainage basin is mostly dominated by lower order streams and the development of stream segments is more or less affected by rainfall. The Suketi river basin is 
a 7th order basin with elongated nature and moderate drainage density. The elongated shape of the drainage basin reveals the guiding effect of palaeotectonic activities resulting in drainage reversal (cf. Bhargava et al. 2011). The asymmetry factor of Suketi river basin indicates tectonic tilting was towards downstream right side of the drainage basin, at the basin level scale.

The overall dendritic to sub-dendritic drainage pattern in Suketi river basin indicates semipervious nature of the soil in the study area. However, occurrence of rectangular and radial drainage pattern at a few locations in the RKSB and GKSB respectively indicates partial structural and lithological control. The 1st and 2nd order streams constitute about $77.93 \%$ and $16.87 \%$ area of the entire drainage basin, respectively, which reflects dominance of relief features in the high altitude mountains with a steep gradient in the zones of 1st and 2 nd order streams. Bifurcation ratios of various stream orders and infiltration numbers of the entire Suketi river basin and sub-basins also reveal a highly dissected and steep gradient mountainous terrain that facilitates high overland flow, rapid runoff, and less water infiltration into the subsurface. This leads to low groundwater potential in the zones of 1st, 2nd and 3rd order streams and causes rampant water scarcity, mostly during summer, in the mountainous terrain as compared to the Balh valley of the Suketi river basin. Higher values of drainage density imply existence of hard, impermeable, and structurally controlled lithology in the mountainous terrain of Suketi river basin. In general, the morphometric analysis of Suketi river basin reveals that the drainage basin is passing through the late youth to early mature stage of development of the fluvial geomorphic cycle.

The slope analysis of Suketi river basin reveals three main slope zones, which are in consonance with major physiographic units of the study area. The first and outermost zone of high altitude mountains has slope of more than $10^{\circ}$ and surrounds the periphery of Suketi river basin. This zone of steep slopes represents the runoff zone. Habitations in this zone are sparse and scattered and mostly occur in the vicinity of perennial source of water, either surface water or subsurface spring sources. Bore wells supplement the water requirements of populace for domestic use in the mountainous terrain, to a certain extent. The hydrogeological studies revealed that many of the spring sources have either dried up or their discharge has been significantly reduced. Spring sources therefore need attention for revival and sustenance by taking suitable artificial recharge measures in the runoff zone. The sites for artificial recharge and rain water harvesting structures have to be identified based on detailed micro level studies within the sub-basins.
The second zone of Suketi river basin is the intermediate zone that has moderate slope between $5^{\circ}$ and $10^{\circ}$. It is the transition zone between high altitude mountains and valley planes. This zone is characterised by mostly piedmont deposits and represents the main recharge zone of the study area. Natural sources of groundwater in this zone are springs and streams that constitute the traditional sources of water for the inhabitants of this area. Bore wells fitted with hand pumps are the additional sources of water. Dug wells are mostly absent in this zone due to high relief features and hard rock formations. Since this zone forms the main recharge area, groundwater moves rapidly along the slopes and oozes out at the foot hills, due to intersection of water table with the ground surface forming depression springs. Owing to this hydrological phenomenon, there is a need for arresting the subsurface flow at higher elevation to sustain the spring sources of this zone.

The third zone is the innermost zone of the study area and has almost plane to gentle slope of $<5^{\circ}$. This zone coincides with the plane area of Balh valley and represents the discharge zone of the Suketi river basin. In this zone, groundwater is developed through dug wells and tube wells. Dug wells mostly derive groundwater from the phreatic aquifers of the valley, whereas tube wells tap the deeper semi-confined to confined aquifers. Dug wells are mostly nonenergized and used for domestic purposes, whereas large scale water supply and irrigation schemes are based on groundwater obtained from the tube wells. A proper plan is required in this zone of Balh valley for sustainable development and management of groundwater resources.

Himalayan terrains are known for their highly fragile nature (Srikantia and Bhargava 1998; Pirta 2006). Any unplanned groundwater developmental activities in this fragile terrain would lead to depletion of precious groundwater resources. Hence, roof-top rain water harvesting and artificial recharge through traditional ponds will be feasible structures in the zones of 1st and 2nd order streams of the Suketi river basin. Land holdings in this zone are limited and agricultural practices are followed on small man-made terraces at feasible locations, therefore farm ponds will be very useful as surface water conservation structures. The zones of 3rd and 4th order streams are suitable for construction of small check dams and other water conservation structures like nalla bunds and farm ponds, besides de-silting of the existing tanks. These water harvesting structures at various identified locations will be suitable to facilitate groundwater recharge in this zone. The higher order streams of 5 th and 6 th order cascading through the valley plane areas are recommended for construction of check dams at suitable locations. Check dam construction is also 
recommended for the groundwater development in shallow phreatic aquifers for both small and large scale water supply. Small water harvesting structures such as percolation tanks are recommended at the valley head to check velocity of runoff, increase water percolation, and improve soil moisture regime. The seepage from such percolation tanks can augment recharge to the surrounding aquifers in this area.

\section{Conclusion}

The Suketi river basin is drained by the river Suketi which is a stream of 7 th order. The mountainous terrain of Suketi river basin is characterised by variation in topography, gradient, and lithology. The elongated nature of the entire drainage basin reveals dominance of strong relief and steep ground slope. The entire drainage basin area reflects late youth to early mature stage of development of the fluvial geomorphic cycle, which is dominated by rain and snow-fed lower order streams.

The bifurcation ratios of various orders indicate that streams up to 3rd order are surging through highly dissected mountainous terrain, which facilitate high overland flow and less recharge into the subsurface resulting into low groundwater potential in the zones of 1st, 2nd and 3rd order streams of the Suketi river basin. The high value of infiltration number also indicates dominance of relief features, resulting in less water infiltration and high runoff in the entire drainage basin and low groundwater potential in the high altitude mountainous terrain.

The asymmetry factor (Af) of Suketi river basin indicates that the palaeo-tectonic tilts at drainage basin scale towards the downstream right side of the drainage basin. The slope map of Suketi river basin has been classified into three main zones, which delineate the runoff zone in the mountains, recharge zone in the transition zone between mountains, and valley plane and discharge zone in the plane areas of Balh valley.

The two distinct physiographic units within the basin have varied ground water resource potential which needs to be conserved, augmented, and managed. The studies also point towards immediate necessity of water conservation measures in the upstream catchment areas of the Suketi river basin, to enhance infiltration of surface runoff into the subsurface for revival and sustenance of the spring sources.

\section{Acknowledgements}

Umesh S Balpande is thankful to the Chairman, CGWB, Faridabad and Regional Director, CGWB,
Nagpur for permission to carry out this work. The help rendered by the officers and staff of CGWB, NHR, Dharmshala and CR, Nagpur is thankfully acknowledged. Authors are thankful to the revered reviewers and Editor of the Journal as their meticulous reviews and patience have improved the paper to a great extent.

\section{References}

Ahmed A and Bhat M A 2012 Tectonic geomorphology of the Rambiara basin, SW Kashmir valley reveals emergent out-of-sequence active fault system; Him. Geol. 33(2) $162-172$.

Ansari Z R, Rao L A K and Alia Yusuf 2012 GIS based morphometric analysis of Yamuna drainage network in parts of Fatehabad area of Agra district, Uttar Pradesh; J. Geol. Soc. India 79 505-514.

Beneduce P, Festa V, Francioso R, Schiattarella M and Tropeano M 2004 Conflicting drainage patterns in the Matera Horst Area, southern Italy; Phy. Chem. Earth 29 $717-724$.

Bhargava O N, Kumbkarni S and Ahluwalia A D 2011 Geomorphology and landforms: Illustrations from the Himachal Himalaya, Technical Publ., Dehradun, 212p.

Burnett A W and Schumm S A 1983 Alluvial river response to neo-tectonic deformation in Louisiana and Mississippi; Science 222 49-50.

Cannon J P 1976 Generation of explicit parameters for a quantitative geomorphic study of the Mill Creek drainage basin, Oklahoma; Geology Notes 36(1) 13-17.

Capolongo D, Cecaro G, Giano S I, Lazzari M and Schiattarella M 2005 Structural control on drainage network of the south-western side of the Agri River upper valley (Southern Apennines, Italy); Geografia Fisica e Dinamica Quaternaria 28 169-180.

CGWB 2001 Master plan for artificial recharge to groundwater in Himachal Pradesh; Central Ground Water Board, Ministry of Water Resources, Govt. of India, NHR, Kangra.

CGWB 2006 Groundwater information booklet, Mandi District, Himachal Pradesh; Central Ground Water Board, Ministry of Water Resources, Govt. of India, NHR, Dharmsala.

CGWB 2007 Manual on artificial recharge of groundwater; Central Ground Water Board, Ministry of Water Resources, Govt. of India, 185p.

Chow V T 1964 (ed.) Handbook of applied hydrology; McGraw Hill Inc, New York, 572p.

Das B K and Haake B G 2003 Geochemistry of Rewalsar lake sediments Lesser Himalaya, India: Implications for source-area weathering, provenance and tectonic setting; Geosci. J. 7(4) 299-312.

Das B K and Kaur P 2007 Geochemistry of surface and subsurface waters of Rewalsar lake, Mandi district, Himachal Pradesh: Constraints on weathering and erosion; J. Geol. Soc. India 69 1020-1030.

Delcaillau B 2001 Geomorphic response to growing faultrelated folds: Example from the foothills of central Taiwan; Geodinamica Acta 14 265-287.

Demoulin A 1998 Testing the tectonic significance of some parameters of longitudinal profiles: The case of the Ardenne (Belgium, NW Europe); Geomorphology 24 189-208.

Gangalakunta P, Reddy O, Maji A K and Gajbhiye K S 2004 Drainage morphometry and its influence on 
landform characteristics in a basaltic terrain, central India - a remote sensing and GIS approach; Intl. J. Appl. Earth Geoinfor. 6 1-16.

Gardner T W, Back W, Bullard T F, Hare P W, Kesel R H, Lowe D R, Menges C M, Mora S C, Pazzaglia F J, Sasowsky I D, Troester J W and Wells S G 1987 Central America and the Caribbean; In: Geomorphic systems of North America: Boulder, Colorado (ed.) Graf W L, Geol. Soc. America, Centennial Spec. Vol. 2 343-401.

Gioia D and Schiattarella M 2010 An alternative method of azimuthal data analysis to improve the study of relationships between tectonics and drainage networks: Examples from southern Italy; Zeitschrift für Geomorphologie $\mathbf{5 4}$ $225-241$.

Gioia D, Schiattarella M, Mattei M and Nico G 2011a Quantitative morphotectonics of the Pliocene to Quaternary Auletta basin, southern Italy; Geomorphology 134 326-343.

Gioia D, Sabato L, Spalluto L and Tropeano M 2011b Fluvial landforms in relation to the geological setting in the 'Murge Basse' karst of apulia (Bari metropolitan Area, Southern Italy); J. Maps 7(1) 148-155.

Gomez F, Barazangi M and Bensaid M 1996 Active tectonics in the intra-continental Middle Atlas Mountains of Morroco: Synchronous crustal shortening and extension; J. Geol. Soc. London 153 389-402.

Hack J T 1957 Studies of longitudinal profiles in Virginia and Maryland; USGS Professional Paper No. 294-B 45-97.

Hack J T 1973 Stream-profile analysis and stream-gradient index; USGS J. Res. 1 421-429.

Hare P W and Gardner T W 1984 Geomorphic indicators of vertical neo-tectonism along converging plate margins, Nicoya Peninsula, Costa Rica; In: Tectonic Geomorphology (eds) Morisawa M and Hack J T, Proc. 15th Geomorphology Symp. Birmingham, Allen \& Unwinr, Boston, pp. 76-104.

Holbrook J and Schumm S A 1999 Geomorphic and sedimentary response of rivers to tectonic deformation: A brief review and critique of a tool for recognizing subtle epirogenic deformation in modern and ancient settings; Tectonophys. 305 287-306.

Horton R E 1932 Drainage basin characteristics; Trans. Am. Geophys. Union 13 350-361.

Horton R E 1945 Erosional development of streams and their drainage basins: Hydrophysical approach to quantitative morphology; Geol. Soc. Am. Bull. 56 275-370.

Keller E A 1986 Investigation of active tectonics: Use of surficial Earth processes; In: Panel on Active Tectonics, National Academy Press, Washington DC, pp. 138147.

Keller E A and Pinter N 2002 Active Tectonics: Earthquakes, Uplift and Landscape; 2nd edn, Prentice Hall, Upper Saddle River, NJ.

Kirby E and Whipple K 2001 Quantifying rock uplift-rates via stream profile analysis; Geology 29(5) 415-418.

Lavé J and Avouac J P 2000 Active folding of fluvial terraces across the Siwalik Hills, Himalayas of Central Nepal; J. Geophys. Res. 105(B3) 5735-5770.

Lavé J and Avouac J P 2001 Fluvial incision and tectonic uplift across the Himalayas of Central Nepal; J. Geophys. Res. 106(B11) 26,561-26,591.

Leopold L B, Wolman M G and Miller J P (eds) 1964 Fluvial processes in geomorphology, Chapter 5, 'Drainage basin as a geometric unit'; W.H. Freeman and Co., San Francisco and London, 522p.

Mackin J H 1948 Concept of the graded river; Geol. Soc. Am. Bull. 59 463-512.

Marple R T and Talwani P 2000 Evidences for a buried fault system in the coastal plain of the Carolinas and
Virginia - Implications for neo-tectonics in the southeastern United States; Geol. Soc. Am. Bull. 112 200220.

Melton M A 1958a Correlation structure of morphometric properties of drainage system and their controlling agents; J. Geol. 66 442-460.

Melton M A 1958b A derivation of Strahler's Channelordering system; J. Geol. 67 345-346.

Merritts D and Vincent K R 1989 Geomorphic response of coastal streams to low, intermediate and high rate of uplift, Mendocino triple junction region, northern California; Geol. Soc. Am. Bull. 101 1373-1388.

Morisawa M 1985 Geomorphology text book: Rivers, forms and process, Chapter 5, 'Structural and lithological control', 390p.

Ouchi S 1985 Response of alluvial rivers to slow active tectonic movement; Geol. Soc. Am. Bull. 96 504-515.

Pakhmode V, Kulkarni H and Deolankar S B 2003 Hydrological drainage analysis in watershed programme planning: A case study from the Deccan basalt, India; Hydrogeol. J. 11 595-604.

Pankaj A and Kumar P 2009 GIS based morphometric analysis of five major sub-watersheds of Song river, Dehradun district, Uttarakhand with special reference to landslide incidences; J. Indian Soc. Remote Sens. 37 157-166.

Patton P C 1988 Drainage basin morphometry and floods; In: Flood Geomorphology (eds) Baker B R, Kochel R C and Patton P C, Wiley Publ., USA, pp. 51-65.

Pirta D K 2006 Himachal Pradesh: The Himalayan State (Geography, History, Culture, Demography and Economy); JMD Publ., Shimla, 319p.

Ponza A, Pazzaglia F J and Picotti V 2010 Thrust-fold activity at the mountain front of the Northern Apennines (Italy) from quantitative landscape analysis; Geomorphology 123 211-231.

Rao K N, Latha S, Kumar P A and Krishna M H 2010 Morphometric analysis of Gostani river basin in Andhra Pradesh State, India using spatial information technology; Int. J. Geomatics and Geosci. 1(2) 179-187.

Rhea S 1989 Evidence of uplift near Charleston, South Carolina; Geology 17 311-315.

Rhea S 1993 Geomorphic observations of the rivers in the Oregon coast range from a regional reconnaissance perspective; Geomorphology 6 135-150.

Roohani M S and Gupta R P 1988 Quantitative hydrogeomorphic investigations in the Chenab catchment Himalayas; Hydrol. J. 11(4) 25-43.

Salvany J M 2004 Tilting neo-tectonics of the Guadiamar drainage basin, SW Spain; Earth Surface Proc. Landforms 29 145-160.

Saud M A 2009 Morphometric analysis of Wadi Aurnah drainage system, western Arabian peninsula; Open Hydrol. J. 3 1-10.

Schumm S A 1956 Evaluation of drainage systems and slopes in badlands at Perth Amboy, New Jersy; Geol. Soc. Am. Bull. 67 597-646.

Schumm S A 1963 Sinuosity of alluvial rivers on the Great Plains; Geol. Soc. Am. Bull. 74 1089-1100.

Schumm S A, Dumont J F and Holbrook J M 2000 Active tectonics and alluvial rivers, Cambridge University Press, Cambridge, 276p.

Seeber L and Gornitz V M 1983 River profiles along the Himalayan arc as indicators of active tectonics; Tectonophys. 92 335-367.

Singh R K, Bhatt C M and Prasad V H 2003 Morphological study of a watershed using remote sensing and GIS techniques; Hydrol. J. 26(1-2) 55-66.

Singh S 1998a Physical Geography; Prayag Pustak Bhawan, Allahabad, India, pp. 234-236. 
Singh S 1998b Geomorphology; Prayag Pustak Bhawan, Allahabad, 613p.

Singh S and Singh M C 1997 Morphometric analysis of Kanhar River Basin; Natl. Geogr. J. India 43(I) 3143.

Smith S 1950 Standards for grading textures of erosional topography; Am. J. Sci. 248 655-668.

Srikantia S V 1987 Himalaya - the collided orogen: A plate tectonic evolution on geological evidences; Tectonophys. 134 75-90.

Srikantia S V 1988 Himalayan thrusts and structural belts; J. Geol. Soc. India 31 210-229.

Srikantia S V and Bhargava O N 1998 Geology of Himachal Pradesh; Geol. Soc. India Memoir, 406p.

Strahler A N 1950 Equilibrium theory of erosional slopes approached by frequency distribution analysis; Am. J. Sci. 248 800-814.
Strahler A N 1952 Dynamic basis of geomorphology; Geol. Soc. Am. Bull. 63 923-938.

Strahler A N 1957 Quantitative analysis of watershed geomorphology; Trans. Am. Geophys. Union 38 913-920.

Strahler A N 1964 Quantitative geomorphology of drainage basin and channel networks; In: Handbook of Applied Hydrology (ed.) Chow V T, Mc Graw Hill Book Co., New York, pp. 4-76.

Tambe S, Kharel G, Arrawatia M L, Kulkarni H, Mahamuni K and Ganeriwala A K 2012 Reviving dying springs: Climate change adaptation experiments from the Sikkim Himalaya; Mountain Res. Dev. 32(1) 62-72.

Vaidyanandan R and Ramakrishnan M 2008 Geology of India; Geol. Soc. India Memoir 2 615-661.

Yeh H F, Lee C H, Hsu K C and Chang P H 2009 GIS for the assessment of the groundwater recharge potential zone; Environ. Geol. 58 185-195. 